\title{
Tip 3 Spinal Muskuler Atrofili Olguya Anestezik Açıdan Yaklaşım
}

\section{Anesthetic Approach to the Patient with Type 3 Spinal Muscular Atrophy}

\author{
Ecem Aydın Koçoğlu ${ }^{1}$, Ismet Topçu ${ }^{1}$, Gönül Tezcan Keleş ${ }^{1}$, Tülün Öztürk ${ }^{1}$, Alp Yentür ${ }^{1}$, Hüseyin Yercan ${ }^{2}$ \\ ${ }^{1}$ Manisa Celal Bayar Üniversitesi Tıp Fakültesi Anesteziyoloji ve Reanimasyon AD, Manisa, Türkiye \\ ${ }^{2}$ Manisa Celal Bayar Üniversitesi Tıp Fakültesi Ortopedi ve Travmatoloji AD, Manisa, Türkiye
}

topcuismet@yahoo.com, ecemaydin888@hotmail.com, gtezkeles@yahoo.com,ozturktulun@yahoo.com, ayentur@yahoo.com, yercanhes@yahoo.com,

ORCID: 0000-0002-1528-1867

ORCID: 0000-0002-2783-2865

ORCID: 0000-0002-6879-5124

ORCID: 0000-0003-1693-6674

ORCID: 0000-0001-5521-0062

ORCID: 0000-0003-2547-0829

*Sorumlu yazar/ Corresponding Author: Ecem Aydın Koçoğlu

Gönderim Tarihi / Received: 03.09.2020

Kabul Tarihi / Accepted: 29.12.2020

DOI: $10.34087 /$ cbusbed. 804790

\section{Öz}

Spinal musküler atrofi (SMA); çoğunlukla otozomal resesif geçişli, 1/10.000 sıklıkta görülen, spinal kord ön boynuz hücreleri ve beyin sapı motor nukleuslarının dejenerasyonu sonucu oluşan kalıtsal bir hastalıktır. Hastalık klinik olarak alt ekstremitelerin proksimal kas güçsüzlüğünden, disfaji ve solunum yetmezliğine kadar ilerleyebilen bir seyir gösterebilmektedir. Bu hastaların anestezi uygulamaları; zor havayolu yönetimi, nöromüsküler bloke edici ajanlara karşı aşırı duyarlılık, kas güçsüzlüğü ve respiratuar kapasitedeki bozukluk nedeniyle genellikle zordur. Bu olgu sunumunda; femur fraktürü nedeniyle cerrahi geçirecek Tip 3 SMA'lı bir hastaya anestezi ve postoperatif analjezi amacıyla başarılı bir kombine spinal-epidural anestezi uygulamasının sunulması amaçlandı.

Anahtar kelimeler: Spinal muskuler atrofi, Kas hastalıkları, Rejyonel anestezi

\section{Abstract}

Spinal muscular atrophy (SMA); it is an inherited disease with mostly autosomal recessive inheritance, seen with a frequency of 1/10000, resulting from degeneration of spinal cord anterior horn cells and brainstem motor nuclei. Clinically, the disease can progress from proximal muscle weakness of the lower extremities to dysphagia and respiratory failure. Anesthesia applications of these patients; difficult airway management is often difficult due to hypersensitivity to neuromuscular blocking agents, muscle weakness and impaired respiratory capacity. In this case report; It was aimed to present a successful combined spinal-epidural anesthesia for anesthesia and postoperative analgesia to a patient with Type 3 SMA who will undergo surgery for a femur fracture.

Keywords: Muscle diseases, Regional anesthesia, Spinal musculer atrophy.

\section{Giriş}

Spinal musküler atrofi (SMA), çoğunlukla otozomal resesif geçişli, 1/10.000 sıklıkta görülen, spinal kord ön boynuz hücreleri ve beyin sapı motor nukleuslarının dejenerasyonu sonucu oluşan kalıtsal bir hastalıktır [1]. Nadiren X'e bağlı resesif veya otozomal dominant geçiş gösteren formlarda da görülebilir. Semptomlar simetrik, progresif ve daha çok proksimal kas gruplarının güçsüzlüğü ile karakterizedir [1,2].
SMA ortaya çıkış yaşına ve kas güçsüzlüğünün şiddetine göre dört alt tipe ayrılır. Şiddetli formu olan Tip 1 SMA ( Werding - Hoffmann hastalığı) hayatın ilk altı ayı içinde ciddi solunum sikıntısı ve hipotoni ile bulgu verir ve hastalar giderek ilerleyen solunum yetersizliği nedeniyle ilk 2 yılda kaybedilir. Tip 2 SMA, doğum sonrası 6 - 18 aylar arasında başlar ve Tip 1'deki kadar hızlı bir klinik kötüleşme göstermez. Tip 3 SMA (Kugelberg Welander) çocukluk çağı SMA'sı olarak da bilinir, 18. 
aydan sonra sıklıkla yürüme güçlüğü ile ortaya çıkar ve bu tipte yaşam süresinde kısalma genellikle görülmez. Tip 4 SMA ise yetişkin çağda başlar [3]. SMA hastalarının şiddetli durumlar dişında duyusal sinir fonksiyonları normaldir [4]. Hastaların entellektüel ve bilişsel işlevleri korunmuştur [2].

Bu olgu sunumunda, SMA Tip 3 tanısı olan bir hastada gelişen femur fraktürü nedeniyle uygulanacak cerrahiye anestezik açıdan yaklaşımın değerlendirilmesi amaçland1.

\section{Olgu Sunumu}

38 yaşında, $65 \mathrm{~kg}$ kadın hasta, femur şaft fraktürü nedeniyle operasyonu planlandığ 1 için ortopedi kliniğine yatırıldı. Onamı alınan hastanın öyküsünde 12 yaşında yürüme bozukluğu nedeniyle doktora başvurduğu ve yapılan kas biyopsisi ile SMA Tip 3 tanısı aldığ1 öğrenildi. Hastanın öyküsünde; anne ve baba arasında akrabalık bulunmuyordu ve ek başka bir hastalığı yoktu. SMA için herhangi bir ilaç kullanımı mevcut değildi.

Yapılan fizik muayenede; hastanın üst ekstremite kas gücünün $4 / 5$, alt ekstremite kas gücünün $3 / 5$ olduğu, destekle yürüdüğü ve omurga deformitesinin bulunmadığı gözlendi. Hastanın sfinkter tonusu, yutma, solunum ve kardiyak fonksiyonları normal olarak kaydedildi. Yapilan laboratuvar tetkiklerinin normal sınırlarda olduğu gözlendi.

Hastaya operasyon sirasındaki anestezi yöntemi olarak kombine spinal-epidural anestezi planlandi. Operasyon odasina alınan hastanın kan basinc1 (KB), elektrokardiyogramı (EKG), kalp atım hızı (KAH), periferik oksijen satürasyonu $\left(\mathrm{SpO}_{2}\right)$, end tidal karbondioksit $\left(\mathrm{ETCO}_{2}\right)$ değeri ve vücut 1 Sısı monitörize edildi. Hastaya yüz maskesi ile 5 litre/dakika'dan (L/dk) oksijen desteği sağlandı. İntravenöz (IV) erişim sağlandıktan sonra premedikasyon için hastaya $1 \mathrm{mg}$ midazolom IV olarak verildi. Sonra hastaya lateral dekübit pozisyonu verilerek L4-L5 intervertebral aralığından 'Espocan' (Braun/Germany) setindeki 18 G Tuohy iğnesiyle direnç kaybı yöntemiyle epidural mesafeye girildi. Setin $27 \mathrm{G}$ Quincke spinal iğnesi ile Tuohy iğnesinin içinden ve arka yüzündeki spinal iğne deliğinden geçerek subaraknoid mesafeye girildi. Beyin omurilik sıvısı (BOS) akışı görüldükten sonra subaraknoid alana 7,5 mg \% $0,5^{\prime}$ lik hiperbarik bupivakain uygulandı ve iğne geri çekildi. Epidural kateter kraniyale yönlendirilmiş şekilde epidural aralıkta $5 \mathrm{~cm}$ ilerletildi ve yerleştirildi. Hasta $10 \mathrm{dk}$ boyunca lateral dekübit pozisyonda bekletildikten sonra supin pozisyona alınd. Supin pozisyonda yapılan muayenesinde duyusal blok 'pinprick' testiyle T10 düzeyindeydi ve motor blok ise Bromage skalasına göre 3 idi. Blok düzeyinin yeterli olduğuna karar verildikten sonra cerrahiye izin verildi. Operasyon yaklaşık $60 \mathrm{dk}$ sürdü ve supine pozisyonda devam etti. Cerrahi süresince herhangi bir komplikasyon yaşanmadı, hastanın hemodinamisi ( kan basıncı, kalp atım hızı ve oksijen satürasyonu ) stabil seyretti. Hasta operasyondan sonra
$30 \mathrm{dk}$ PACU (postanestezik bakım ünitesi) da takip edildi ve vital bulgularının stabil olması üzerine servise taburcu edildi. Servis takibinde postoperatif yaklaşık 90. dk'da motor bloğu sona eren hastaya epidural kateterden hasta kontrollü analjezi (PCA) cihazı ile hastane protokolümüze uygun dozlarda bupivakain - fentanyl infüzyonu başlandı ve 24 saat infüzyon devam etti. Postoperatif 24. saatinde VAS (visual analog scale) 3 olması üzerine epidural kateteri çekilen hastada herhangi bir nörolojik komplikasyon yaşanmadi. Hasta postoperatif 5. günde evine taburcu edildi.

\section{Tartışma}

SMA'lı hastalara tanı testleri, kas biyopsileri veya cerrahi operasyonlar için anestezi uygulamaları gerekebilmektedir. Cerrahi operasyonlar da sıklıkla osteotomi, tendon gevşetme ve spinal enstrümantasyon gibi ortopedik girişimlerdir [5]. Bu hasta grubunda standart bir anestezi yöntemi bulunmamaktadır. SMA'l1 hastaların cerrahilerinde genel anestezi veya rejyonal anestezi yöntemleri seçilebilir. Anestezi yönetimine karar verilirken hastaların postoperatif ağrı tedavileri de planlanmalıdır. Çünkü postoperatif ağrı iyi yönetilmezse komplikasyonlara ve uzun süreli rehabilatasyona neden olur (6). Anesteziye bağlı oluşabilecek riskler SMA'nın tipleri arasında ciddi farklılıklar göstermektedir. Bu risklerden bazıları; havayolu yönetiminde zorluklar, postoperatif yoğun bakım ihtiyacına yol açabilen solunum yetmezliği, gastroözofageal reflü ve kas gevşetici kullanımındaki kısıtlamalar şeklinde siralanabilir [6].

SMA'lı hastalarda önemli anestezik problem havayolu kontrolü ve zor entübasyondur. Geçirilmiş spinal cerrahi ile eklem kontraktürlerinin varlığı servikal vertebranın sınırlı hareket etmesine neden olmaktadır. A $\breve{g} 1 z$ açıklığının azalması, yaşın ilerlemesi ile paralellik gösterip mandibular eklemin ankilozuna sekonder oluşabilmektedir. Özellikle SMA Tip 2 hastalarında \% 30 oranında ağız açıklığında güçlük olduğu ve ilerleyen yaşlarda bu oranın \% 80'e kadar yükselebileceği tespit edilmiştir [7]. SMA'lı olgularda entübasyon güçlüğü nedeniyle ölüme kadar varabilen komplikasyonların yaşanabildiği bildirilmiştir [8]. Zor entübasyon olduğu düşünülen SMA'lı olgularda laringeal maske (LMA), fiberoptik entübasyon, retrograd entübasyon ve video laringoskop başarı ile uygulanmıştır [6]. LMA kullanıldığında, özellikle SMA Tip 1 ve 2 olgularında sık görülen gastroözofageal reflü açısından dikkatli olunmalıdir [5].

SMA'lı hastalarının solunum fonksiyonlarında ilerleyen kötüleşme ve dispne yaygın olarak görülebilmektedir. İnspiratuar kaslardaki zayıflık solunum yetmezliğine sebep olabilirken, ekspiratuar kaslardaki zayıflık ise yetersiz öksürme ve sekresyon atılımı sonucu kronik atelektaziye sebep olabilir [9]. Şiddetli omurga deformitelerinin varlığında da çeşitli derecelerde restriktif akciğer hastalığı mevcut olabilir. Omurga deformitelerinin sıklıkla eşlik ettiği olguların yaklaşık \% 
20'sinde kraniyal sinirlerin (V, VII, IX, XII) tutulumuyla bulbar disfonksiyon ve disfaji gelişmektedir [10]. Bu hastalarda solunum rezervi azalmış ve solunum fonksiyonları bazal düzeyde kalmıştır. Bu tür hastaların postoperatif dönemde yoğun bakım ünitesinde takip ihtiyacı olabilir. Küçük cerrahi girişimlerden sonra bile hastanede uzun yatış süreleri gerekebildiği bildirilmiştir [5].

SMA'lı olguların genel anestezi uygulamalarında, entübasyon güçlüğü ve kas gevşetici kullanımına bağlı sık karşılaşılan uzamış solunum yetmezliği problemi için kullanılacak ilaçlarda bir netlik yoktur [11]. Anestezik ajanlardan dikkat edilmesi gerekenler opioidler ve nöromuskuler blokerlerdir [5]. SMA olgularında nöromüsküler kavşaktaki asetilkolin miktarındaki azalma, kolinasetiltransferaz ve asetilkolinesteraz sekresyonunda azalmaya neden olur. $\mathrm{Bu}$ da nondepolarizan kas gevşetici ajanlara karşı aşırı duyarlılığa ve etkilerinin uzamasına neden olur [12]. Süksinilkolin kullanımı rabdomiyolizis ve hiperpotasemiye neden olabilir. Ancak bu hasta grubunda süksinilkolin kullanımına bağlı hiperkalemi veya farklı yan etki bildirilmemiștir [13]. Tüm opioidler perioperatif dönemde SMA olgularında kullanılmıştır. Postoperatif analjezi amaçlı opioid kullanımlarında hastalar solunum rezervlerinin kisitlı olması nedeniyle solunum depresyonu açısından yakın izlenmelidir. Kısa etkili opioid ajanların kullanımı SMA'lı hastalar için daha uygun bir seçenektir [5].

Habib ve ark. SMA'lı hastaların anestezi indüksiyonunda endotrakeal entübasyonu için propofol+alfentanil kombinasyonunun alternatif bir yöntem olabileceğini vurgulamışlardır [14]. Neumann ve ark. ise anatomik malformasyonlar ve kontraktürler nedeniyle entübasyon güçlüğü (Mallampati 4, ağız açıklığı $12 \mathrm{~mm}$ ) bulunan Tip 3 SMA'lı bir gebede kas gevşetici kullanmadan deksmedetomidin infüzyonu ile fiberoptik entübasyon uygulanan bir hastayı bildirmişlerdir [11].

SMA hastalarında otonomik disfonksiyon gözlenmediği için, rejyonal anestezi nedeniyle oluşabilecek sempatik bloğa bağlı kan basıncındaki değişiklikler diğer nöromüsküler hastalıklara göre daha kolay kontrol altına alınabilir [12]. SMA tanılı olguların anestezi yönetiminde önerilen bir kılavuz bulunmamaktadır. Anesteziye bağlı komplikasyonlar hastalığın kendi alt grupları arasında önemli farklılıklar gösterebilmektedir. Bunun yanı sıra SMA'lı hastaların entellektüel ve duygusal kapasitelerinin normal olduğu perioperatif değerlendirme yapılırken akılda tutulmalıdır.

Olgumuzda, omurga deformitesi bulunmadığı için rejyonel anestezi uygulamasının başarılı olacağını düşündük. SMA'lı olguların anestezi uygulamalarında rejyonal anestezi seçimi; bu hastaların hava yolu yönetimindeki zorluklardan, preoperatif ve postoperatif solunumsal problemlerden ve anestezik ilaçlara karşı öngörülemeyen yanıtlardan kaçınılması gibi avantajlar sağlar.

$\mathrm{Bu}$ olgu sunumunda; SMA'lı ve femur cerrahisi geçirecek bir hastada kombine spinal-epidural anestezi yönteminin perioperatif anestezi ve postoperatif analjezi için başarıyla kullanılabileceğini vurgulamak istedik.

\section{Referanslar}

1. Lunn, M.R, Wang, C.H, Spinal muscular atrophy, Lancet, 2008, 371(9630), 2120-33.

2. Wang, C.H, Finkel, R.S, Bertini, E.S, Schroth, M, Simonds, A, Wong, B, et al, Consensus statement for standard of care in spinal muscular atrophy, Journal of Child Neurology, 2007, 22(8), 1027-49.

3. Strober, J.B, Tennekoon, G.I, Progressive Spinal Muscular Atrophies, Journal of Child Neurology, 1999 ;14(11): 691-5.

4. Rudnik-Schöneborn, S, Goebel, H.H, Schlote, W. et al, Classical infantile spinal muscular atrophy with SMN deficiency causes sensory neuronopathy, Neurology, 2003, 25, 60(6), 983-7.

5. Graham, R.J, Athiraman, U, Laubach, A.E, Sethna, N.F, Anesthesia and perioperative medical management of children with spinal muscular atrophy, Paediatric Anaesthesia, 2009,19(11),1054-1063.

6. Karadağ Arlı, Ş, Cerrahi Bakımda Ağrı Yönetimine İlişkin Hemșirelik Girișimleri, Celal Bayar Üniversitesi Sağllk Bilimleri Enstitüsü Dergisi, 2017, 4(3), 1013-1020.

7. Islander, G, Anesthesia and spinal muscle atrophy, Paediatric Anaesthesia, 2013, 23(9), 804-816.

8. Messina, S, Pane, M, De Rose, P, et al, Feeding problems and malnutrition in spinal muscular atrophy type II, Neuromuscular Disorders, 2008, 18(5), 389-393.

9. Bach, J.R, The use of mechanical ventilation is appropriate in children with genetically proven spinal muscular atrophy type 1: the motion for, Paediatric Respiratory Reviews, 2008, 9(1), 45-50.

10. Maruotti, G.M, Anfora, R, Scanni, E. et al, Anesthetic management of a parturient with spinal muscular atrophy type II, Journal of Clinical Anesthesia, 2012, 24(7), 573-577.

11. Talbot, K, Davies, K.E, Spinal Muscular Atrophy, Seminars in Neurology, 2001, 21(2), 189-97.

12. Neumann, M.M, Davio, M.B, Macknet, M.R, Applegate, R.L 2nd, Dexmedetomidine for awake fiberoptic intubation in a parturient with spinal muscular atrophy type III for cesarean delivery, International Journal of Obstetric Anesthesia, 2009, 18(4) 403-7.

13. Özhan, M.Ö, Süzer, M.A, Eşkin, M.B, Çaparlar, C, Atik, B, Fener N, Tip III spinal musküler atrofili bir gebenin sezaryen operasyonunda kombine spinal epidural anestezi uygulamas1, Anestezi Dergisi, 2012, 20(2), 119-122.

14. Beach, T.P, Stone, W, Hamelberg, W, Circulatory collapse following succinylcholine: report of a patient with diffuse lower motor neuron disease, Anesthesia and Analgesia, 1971, 50(3), 431-437.

15. Habib, A.S, Helsley, S, Millar, S, Deballi, P, 3rd, Muir, H.A, Anesthesia for cesarean section in a patient with spinal muscular atrophy, Journal of Clinical Anesthesia, 2004,16(3), 217-9.

http://edergi.cbu.edu.tr/ojs/index.php/cbusbed isimli yazarın CBU-SBED başlıklı eseri bu Creative Commons Alıntı-Gayriticari4.0 Uluslararası Lisansı ile lisanslanmıştır.

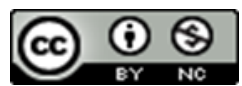

